\title{
PENGENDALIAN Vibrio harveyi PADA LARVA KEPITING BAKAU (Scylla serrata FORSKAL) MELALUI DESINFEKSI INDUK SELAMA PENGERAMAN TELUR
}

\author{
Des Roza* dan Fris Johnny*
}

\begin{abstract}
ABSTRAK
Vibrio harveyi merupakan salah satu patogen pada pembenihan kepiting bakau dan dapat menginfeksi telur maupun larva. Tujuan percobaan ini adalah untuk mengetahui efektivitas tiga jenis antibiotik sebagai desinfektan pada induk yang sedang mengerami telur dalam mencegah infeksi Vibrio harveyi pada telur dan larva kepiting bakau. Vibrio harveyi diisolasi dari larva kepiting bakau stadia zoea-1 yang terinfeksi. Larva kepiting bakau rentan terhadap Vibrio harveyi di mana pada perlakuan infeksi pada kepadatan $10^{5}, 10^{4}, 10^{3}$ dan $10^{2} \mathrm{cfu}, \mathrm{mL}$ media mortalitasnya masing-masing sebesar 72,33\%, 64,33\%, 52,00\% dan 27,33\%, sedangkan pada kontrol (tanpa infeksi Vibrio harveyi) hanya sebesar 3,33\%. Tiga jenis antibiotik uji yang digunakan yaitu oksitetrasiklin (OTC), prefuran dan furazolidon dengan konsentrasi efektif terendah masing-masing $31,2 \mathrm{mg} / \mathrm{L}, 7,8 \mathrm{mg} / \mathrm{L}$ dan $31,2 \mathrm{mg} / \mathrm{L}$. Setelah diaplikasikan untuk mendesinfeksi induk yang sedang mengerami telur yang diinfeksi dengan $V$. harveyi pada kepadatan $10^{3} \mathrm{cfu} / \mathrm{mL}$ ternyata perlakuan antibiotik pada konsentrasi efektif terendah dapat mengurangi jumlah $V$. harveyi serta dapat meningkatkan daya tetas telur dan kinerja larva kepiting bakau.
\end{abstract}

\begin{abstract}
Control of Vibrio harveyi on larvae of mangrove crab (Scylla serrata Forskal) by disinfection of spawner during egg incubation. By: Des Roza and Fris Johnny.
\end{abstract}

Vibrio is one of potential pathogen during larval rearing of mangrove crab (Scylla serrata Forskal). Purpose of this experiment was to know the effectivity of three kinds of antibiotics as disinfectant of the spawner during egg incubation to prevent Vibrio harveyi infection of their eggs and larvae. Vibrio harveyi were collected from infected mangrove crab larvae at zoea-1 stage. The larvae of mangrove crab was very sensitive to $V$. harveyi infection. It was shown that from artificial infection at a density of $10^{5}, 10^{4}, 10^{3}$ and $10^{2} \mathrm{cfu} / \mathrm{mL}$ of media, the mortality of larvae were $72.33 \%, 64.33 \%, 52.00 \%$ and $27.33 \%$ respectively, while to the control (uninfected), was only $3.33 \%$. Three kinds of antibiotics namely oxytetracycline (OTC), prefuran and furazolidone were tested in this experiment and the result revealed that the minimum effectivity concentrations were $31.2 \mathrm{mg} / \mathrm{L}, 7.8 \mathrm{mg} / \mathrm{L}$ and $31.2 \mathrm{mg} / \mathrm{L}$ respective. Application of these antibiotics at their minimum effective concentrations on crab spawner during egg incubation which had been infected with $V$. harveyi at a density $10^{3} \mathrm{cfu} / \mathrm{mL}$ resulted in the reduction of number of Vibrio harveyi and increased the hatching rate as well as larval performance.

KEYWORDS: Scylla serrata Forskal, Vibrio harveyi, antibiotic.

\section{PENDAHULUAN}

Teknologi perbenihan kepiting bakau sudah diaplikasikan dalam memproduksi larva secara massal dan komersial, namun sintasan larva sangat bervariasi karena mortalitasnya masih tinggi terutama pada awal stadia larva. Beberapa penyebab mortalitas pada larva tersebut adalah karena tidak tersedianya pakan alami yang dibutuhkan (Yunus et al., 1998), kualitas air yang jelek serta tidak tertutup kemungkinan adanya serangan penyakit akibat infeksi bakteri terutama Vibrio (Muroga et al., 1989) yaitu V. harveyi (Roza et al., 1993; Roza, 1997). Infeksi $V$. harveyi membahayakan larva kepiting bakau terutama pada awal dan akhir stadia zoea dan megalopa (Yunus et al., 1998). Larva juga rentan terhadap infeksi oleh jamur (Bian et al., 1979; Hatai \& Lawhavinit, 1988; Zafran et al., 1993; Roza, 1996; Roza et al., 1997). Jamur yang dilaporkan sering menginfeksi larva kepiting bakau adalah dari kelompok Lagenidiales terutama Haliphthoros dan Lagenidium. Secara mikroskopis umumnya larva kepiting bakau sudah terinfeksi sejak pengeraman telur atau masa inkubasi (Roza, 1996).

Seperti halnya krustase lainnya, larva kepiting bakau rentan terhadap infeksi $V$. harveyi di mana pada kepadatan $10^{3} \mathrm{cfu} / \mathrm{mL}$ sudah dapat menyebabkan mortalitas yang tinggi yaitu lebih besar

") Peneliti pada Loka Penelitian Perikanan Pantai Gondol 
dari 50\% (Roza et al., 1993; Roza, 1997). Selama ini upaya untuk mencegah infeksi $V$. harveyi yang banyak dilakukan adalah dengan mencuci maupun merendam larva yang baru menetas meng. gunakan antibiotik, tetapi cara ini kurang efektif karena umumnya infeksi terjadi sejak masa pengeraman telur.

Berdasarkan hal tersebut perlu dilakukan pencegahan sedini mungkin yakni dengan desinfeksi induk pada masa pengeraman telur menggunakan antibiotik yang umum digunakan di kalangan praktisi pembenihan dan mudah didapat di pasaran dengan harga yang relatif murah. Tujuan dari percobaan ini adalah untuk mengetahui efektivitas antibiotik sebagai desinfektan dalam mencegah infeksi $V$. harveyi pada larva kepiting bakau. Teknologi yang dihasilkan dalam percobaan ini diharapkan dapat meningkatkan sintasan larva kepiting bakau.

\section{BAHAN DAN METODE}

\section{Isolasi Vibrio harveyi}

Bakteri Vibrio harveyi yang digunakan dalam percobaan ini diisolasi dari larva kepiting bakau stadia zoea-1 yang terinfeksi, di mana pada pengamatan di malam hari larva kelihatan menyala seperti kunang-kunang. Terhadap bakteri yang terdapat pada larva kepiting bakau tersebut dilakukan isolasi dengan cara menggerus larva tersebut dan mengkultur bakteri pada media selektif untuk bakteri Vibrio yaitu TCBSA (Thiosulfate Citrate Bile Salt Sucrose Agar). Selanjutnya media tersebut diinkubasikan pada suhu $25{ }^{\circ} \mathrm{C}$ selama 24 jam dan terhadap koloni bakteri yang tumbuh dilakukan pengamatan dalam kondisi gelap agar kelihatan koloni yang bercahaya bila ada. Koloni yang memproduksi cahaya dimurnikan dengan cara memindahkannya ke media MA (Marine Agar) dan disimpan untuk percobaan berikutnya. Bakteri ini diuji secara biologi dan biokimia dalam rangkaian proses identifikasi dengan berpedoman pada Baumann et al. (1984) dan Holt et al. (1994).

\section{Tingkat Patogenisitas Vibrio harveyi terhadap Larva Kepiting Bakau}

Percobaan ini bertujuan untuk mengetahui tingkat kerentanan larva kepiting bakau terhadap $V$. harveyi dengan cara infeksi buatan. Ke dalam 15 botol kaca yang berisi masing-masing $2 \mathrm{~L}$ air laut yang sudah disterilkan dimasukkan larva kepiting bakau stadia zoea-1 sebanyak 100 ind./L. Ke dalam setiap tiga botol kaca yang dipilih secara acak diinokulasikan suspensi bakteri $V$. harveyi sehingga kepadatan mencapai masing-masing $10^{2}$, $10^{3}, 10^{4}$ dan $10^{5} \mathrm{cfu} / \mathrm{mL}$ media. Sedangkan tiga botol lainnya dijadikan sebagai kontrol dan tidak diinokulasi dengan suspensi $V$. harveyi. Setelah 24 jam infeksi, dilakukan penghitungan mortalitas larva kepiting bakau.

\section{Uji Konsentrasi Efektif Terendah Antibiotik terhadap Vibrio harveyi}

Percobaan ini bertujuan untuk mengetahui konsentrasi efektif terendah dari ketiga antibiotik uji dalam menekan pertumbuhan $V$. harveyi. Antibiotik yang digunakan dalam percobaan ini adalah oksitetrasiklin (OTC), prefuran dan furazolidon yang dapat diperoleh di pasar. Konsentrasi masing-masing antibiotik dibuat menggunakan metode pengenceran 1:1 secara berangkai dalam larutan pepton yang mengandung $1 \% \mathrm{NaCl}$, dengan kisaran konsentrasi antara 0,1-500 mg/L. Pengenceran diawali dengan membuat larutan yang mengandung $500 \mathrm{mg} / \mathrm{L}$ antibiotik, kemudian diencerkan (1:1) sehingga konsentrasi antibiotik menjadi $250 \mathrm{mg} / \mathrm{L}$. Pengenceran demikian seterusnya dilakukan secara berangkai sehingga diperoleh konsentrasi akhir antibiotik sebesar 0,1 mg/L. Dengan demikian konsentrasi antibiotik uji dalam percobaan ini adalah $500 ; 250 ; 125 ; 62,5$; 31,$2 ; 15,6 ; 7,8 ; 3,9 ; 1,9 ; 0,9 ; 0,4 ; 0,2$ dan $0,1 \mathrm{mg} / \mathrm{L}$. Setiap konsentrasi diuji dengan tiga kali ulangan. Ke dalam tabung reaksi yang berisi antibiotik dengan berbagai tingkat konsentrasi diinokulasikan suspensi $V$. harveyi (setara dengan McFarland Equivalence Turbidity Standard 1.0) masingmasing satu ose Selanjutnya tabung reaksi tersebut diinkubasikan pada suhu $25{ }^{\circ} \mathrm{C}$ selama 24 jam. Konsentrasi efektif terendah dari masing-masing antibiotik dalam menekan pertumbuhan $V$. harveyi diketahui dari beningnya larutan pepton dalam tabung reaksi yang menandai tidak adanya pertumbuhan $V$. harveyi. Sedangkan pada konsentrasi yang tidak efektif terlihat dengan jelas larutan pepton berwarna keruh yang menandakan terjadinya pertumbuhan $V$. harveyi. Untuk lebih meyakinkan, dilakukan reisolasi dengan cara mengkultur 0,1 mL suspensi dari berbagai konsentrasi antibiotik pada media TCBSA, kemudian diinkubasikan pada suhu $25^{\circ} \mathrm{C}$ selama 24 jam, setelah itu diamati terjadinya pertumbuhan koloni bakteri.

\section{Desinfeksi Induk selama Masa Inkubasi dengan Antibiotik untuk Pengendalian Vibrio harveyi pada Larva Kepiting Bakau}

Percobaan ini dilakukan untuk mengetahui konsentrasi efektif terendah dari antibiotik dalam pengendalian $V$. harveyi pada larva kepiting bakau 
melalui desinfeksi induk. Induk kepiting bakau vang digunakan dalam percobaan ini diperoleh dari petani pengumpul di daerah Pasuruan dan Probolinggo, Jawa Timur. Induk kepiting bakau yang: matang telur dipelihara secara terkontrol dalam bak penampungan dengan sistem air mengalir. Setelah telur siap untuk ditetaskan, masing-masing induk diinkubasikan dalam bak polikarbonat (1 ekor/bak) yang berisi air laut yang telah diperlakukan dengan disinari UV dan ozonisasi sebanyak $300 \mathrm{~L}$, kemudian diinfeksikan $V$. harveyi dengan kepadatan $10^{3} \mathrm{cfu} / \mathrm{mL}$ dan selanjutnya ditambahkan antibiotik yaitu OTC, prefuran dan furazolidon. Konsentrasi masingmasing antibiotik berdasarkan hasil uji konsentrasi efektif terendah pada percobaan sebelumnya. Setelah telur menetas dilakukan pengamatan terhadap keberadaan $V$. harveyi dalam tubuh larva kepiting bakau dengan cara mengkultur larva pada media TCBSA. Apabila dari reisolasi tidak ada pertumbuhan $V$. harveyi maka antibiotik pada konsentrasi tersebut efektif untuk menanggulangi $V$. harveyi. Selain itu juga dilihat pengaruhnya terhadap daya tetas telur dan kinerja larva kepiting bakau. Pengamatan kinerja larva (morfologi dan kelincahan gerak) dilakukan secara visual.

\section{HASIL DAN BAHASAN}

\section{Isolat Vibrio harveyi}

Isolat $V$. harveyi yang diisolasi dari larva kepiting bakau zoea-1 hasil penetasan di panti benih Loka Penelitian Perikanan Pantai Gondol, Bali, mempunyai karakter antara lain koloni berwarna hijau pada media TCBSA, tidak dapat mensintesis sukrose, tumbuh pada suhu $20-35^{\circ} \mathrm{C}$, memproduksi cahaya, serta sensitif terhadap novobiosin dan agen vibriostatik (Tabel 1). Karakter $V$. harveyi yang diisolasi dari larva kepiting bakau ini memperlihatkan kesamaan dengan $V$. harveyi yang diisolasi dari larva udang windu (Roza et al., 1993: Roza, 1996; Roza et al., 1997).

\section{Tingkat Patogenisitas Vibrio harveyi terhadap Larva Kepiting Bakau}

Setelah 24 jam infeksi $V$. harveyi pada semua perlakuan kepadatan bakteri terlihat mortalitas larva yang tinggi. Mortalitas tertinggi diperoleh pada perlakuan kepadatan $V$. harveyi $10^{5} \mathrm{cfu} / \mathrm{mL}$ sebesar $72,33 \%$ diikuti $10^{4} \mathrm{cfu} / \mathrm{mL}$ sebesar $64,33 \%$, $10^{3} \mathrm{cfu} / \mathrm{mL}$ sebanyak $52,00 \%$ dan $10^{2} \mathrm{cfu} / \mathrm{mL}$ adalah $27.33 \%$ (Tabel 2). Sedangkan pada kontrol mortalitas yang terjadi hanya sebesar 3,33\%. Jelas terlihat bahwa keberadaan $V$. harveyi sangat mempengaruhi mortalitas larva kepiting bakau. Dari hasil percobaan terlihat bahwa larva kepiting bakau lebih rentan terhadap infeksi $V$. harveyi dibandingkan dengan larva udang windu (Roza et al., 1993; Roza et al., 1997).

\section{Uji Konsentrasi Efektif Terendah Antibiotik terhadap Vibrio harveyi}

Dari tiga antibiotik yang diuji yaitu OTC. prefuran dan furazolidon diperoleh nilai konsentrasi efektif terendah masing-masing pada $31,2 \mathrm{mg} /$ $\mathrm{L}, 7,8 \mathrm{mg} / \mathrm{L}$ dan $31,2 \mathrm{mg} / \mathrm{L}$ (Tabel 3).

Dari pengamatan visual (kekeruhan) terlihat bahwa prefuran pada konsentrasi $3,9 \mathrm{mg} / \mathrm{L}$ dan OTC atau furazolidon pada konsentrasi $15,6 \mathrm{mg} / \mathrm{L}$ sudah dapat menghambat pertumbuhan Vibrio harveyi, namun dari hasil reisolasi pada media TCBSA, pada perlakuan konsentrasi tersebut. Vibrio harveyi terbukti masih dapat tumbuh.

Penentuan konsentrasi merupakan hal yang sangat penting pada tahap aplikasi karena kesalahan dalam menentukan konsentrasi pemakaian antibiotik merupakan tindakan fatal, dan akan berdampak pada terbentuknya kekebalan bakteri terhadap antibiotik tersebut. Konsentrasi yang sudah diketahui inipun harus diteliti lagi untuk kontinyuitas pemakaiannya, biasanya setelah 2-3 bulan pemakaian, konsentrasi efektif terendah ini harus diteliti ulang. Aoki (1992) menyatakan bahwa pemakaian antibiotik secara terus-menerus dapat memacu kekebalan melalui transfer AR-plasmid dalam DNA bakteri. Proses terbentuknya kekebalan ini terjadi dalam waktu yang sangat cepat dan gejala ini juga dilaporkan terjadi di Thailand (Ruangpan \& Kitao, 1992), Jepang (Aoki, 1992) serta Filipina (Baticados \& Paclibare, 1992)

\section{Desinfeksi Induk selama Masa Inkubasi dengan Antibiotik untuk Pengendalian Vibrio harveyi pada Larva Kepiting} Bakau

Hasil percobaan menunjukkan bahwa melalui desinfeksi induk menggunakan antibiotik selama masa pengeraman telur dapat mengendalikan $V$. harveyi. Terlihat pada masing-masing perlakuan konsentrasi efektif terendah dari ketiga antibiotik mampu menekan pertumbuhan $V$. harveyi, sehingga kepadatan $V$. harveyi yang diisolasi dari larva kepiting bakau yang baru menetas jauh lebih sedikit dibanding dengan kontrol (tanpa antibiotik). Sedangkan dari pengamatan terhadap daya tetas telur dan kualitas larva terlihat bahwa pada induk yang didesinfeksi, daya tetas telur lebih tinggi dan 
Tabel 1. Karakteristik isolat Vibrio harveyi yang diisolasi dari larva kepiting bakau stadia zoea1 dibandingkan dengan $V$. harveyi menurut Baumann et al. (1984) dan Holt et al. (1994).

Table 1. Characteristic of Vibrio harveyi isolated from larvae of mangrove crab zoea-1 stage by Baumann et al. (1984) and Holt et al. (1994).

\begin{tabular}{|c|c|c|c|}
\hline $\begin{array}{c}\text { Karakteristik } \\
\text { Characteristics }\end{array}$ & $\begin{array}{c}\text { Isolat } \\
\text { Isolate } \\
\end{array}$ & $\begin{array}{c}\text { Báumann } \\
\text { et al. (1984) }\end{array}$ & $\begin{array}{c}\text { Holt et al. } \\
(1994)\end{array}$ \\
\hline Pewarnaan gram (Gram stain) & - . & . & - \\
\hline Katalase (Catalase) & + & + & + \\
\hline Oksidase (Oxydase) & + & + & + \\
\hline Uji O-F (O-F test $)$ & $\mathrm{F}$ & $\mathrm{F}$ & $\mathrm{F}$ \\
\hline Motilitas (Motility) & + & + & + \\
\hline $\mathrm{H}_{2} \mathrm{~S}$ & . & - & - \\
\hline Indol & + & + & + \\
\hline Gas dari glukose (Gas from glucose) & - & - & - \\
\hline L-Arginin (L-Arginine) & + & + & + \\
\hline L-Ornithin (L-Ornithine) & - & - & - \\
\hline Gelatin (Gelatine) & + & + & + \\
\hline \multicolumn{4}{|l|}{ Asam dari (Acid from): } \\
\hline - Selobiose (Cellobiose) & + & + & + \\
\hline - Glukose (Glucose) & + & + & + \\
\hline - Manose (Mannose) & + & + & + \\
\hline - Sorbitol & - & - & - \\
\hline - Sukrose (Sucrose) & - & - & - \\
\hline Bercahaya (Luminescent) & + & + & + \\
\hline \multicolumn{4}{|l|}{$\begin{array}{l}\text { Tumbuh pada suhu (Growth at } \\
\text { temperature): }\end{array}$} \\
\hline$-35\left({ }^{\circ} \mathrm{C}\right)$ & + & + & + \\
\hline$-42\left({ }^{\circ} \mathrm{C}\right)$ & - & - & - \\
\hline \multicolumn{4}{|l|}{ Toleransi terhadap $\mathrm{NaCl}$ (Growth in $\mathrm{NaCl}$ ): } \\
\hline$-0.0 \%$ & - & - & - \\
\hline$-0.5 \%$ & + & + & + \\
\hline$-3.0 \%$ & + & + & + \\
\hline$-6.0 \%$ & + & + & + \\
\hline$-10.0 \%$ & . & - & - \\
\hline \multicolumn{4}{|l|}{ Sensitif terhadap (Sensitivity to): } \\
\hline - Agen vibriostatik (Vibriostatic agent) & $\mathrm{S}$ & S & $\mathrm{S}$ \\
\hline - Novobiosin (Novobiocin) & $\mathrm{S}$ & $\mathrm{s}$ & $\mathrm{S}$ \\
\hline $\begin{array}{l}\text { Warna koloni pada TCBSA (Colour of } \\
\text { colony) }\end{array}$ & $\mathrm{H}$ & $\mathrm{H}$ & $\mathrm{H}$ \\
\hline
\end{tabular}

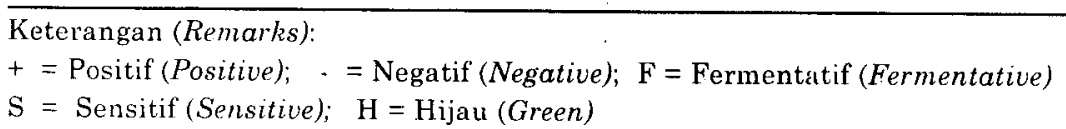

daya gerak larva lebih baik dibandingkan dengan kontrol (tanpa desinfeksi) (Tabel 4).

Pada percobaan ini juga diuji penggunaan konsentrasi yang lebih tinggi dari konsentrasi efektif terendah dari masing-masing antibiotik tersebut tetapi tidak memberikan hasil yang diharapkan, karena induk yang diberi perlakuan dengan antibiotik pada konsentrasi tinggi tersebut mengalami rontok telur. Dari pengamatan secara mikroskopis terlihat bahwa embrio tidak mengalami perkembangan.

Pengendalian patogen pada larva kepiting bakau lebih efektif apabila dilakukan sejak dini terutama pada saat induk mengerami telur karena 
Tabel 2. Tingkat patogenisitas Vibrio harveyi terhadap larva kepiting bakau stadia zoea-1 selama 24 jam pengamatan.

Table 2. Phatogenicity of Vibrio harveyi on larvae of mangrove crab zoea-1 stage during 24-hour observation.

\begin{tabular}{cc}
\hline $\begin{array}{c}\text { Perlakuan kepadatan V.harveyi } \\
\text { Density of V.harveyi } \\
\text { (cfu/mL media) }\end{array}$ & $\begin{array}{c}\text { Mortalitas rata-rata } \\
\text { Average mortality } \\
\text { (\%) }\end{array}$ \\
\hline 105 & $72.33 \pm 0.5774^{\mathrm{e}}$ \\
104 & $64.33 \pm 3.5119^{\mathrm{d}}$ \\
103 & $52.00 \pm 2.6458^{\mathrm{c}}$ \\
102 & $27.33 \pm 4.0415^{\mathrm{b}}$ \\
Kontrol (Control) & $3.33 \pm 1.1547^{\mathrm{a}}$
\end{tabular}

* Angka mortalitas rata-rata yang dikuti oleh huruf yang sama menunjukkan perbedaan yang tidak nyata secara statistik $(P>0,05)$

Averages in coloumn with the same superscript are not significantly different $(P>0.05)$

Tabel 3. Konsentrasi efektif terendah (pengamatan kekeruhan) oksitetrasiklin, prefuran dan furazolidon terhadap Vibrio harveyi.

Table 3. Minimal effective concentration of oxytetracycline, prefuran and furazolidone on Vibrio harveyi.

\begin{tabular}{|c|c|c|c|c|c|c|c|c|c|}
\hline \multirow{4}{*}{$\begin{array}{c}\text { Konsentrasi } \\
\text { Concentration } \\
(\mathrm{mg} / \mathrm{L})\end{array}$} & \multicolumn{9}{|c|}{ Antibiotik (Antibiotics) } \\
\hline & \multicolumn{9}{|c|}{ Pertumbuhan bakteri (Growth of bacteria)* } \\
\hline & \multicolumn{3}{|c|}{$\begin{array}{l}\text { Oksitetrasiklin } \\
\text { Oxytetracycline }\end{array}$} & \multicolumn{3}{|c|}{ Prefuran } & \multicolumn{3}{|c|}{$\begin{array}{c}\text { Furazolidon } \\
\text { Furazolidone }\end{array}$} \\
\hline & 1 & 2 & 3 & 1 & 2 & 3 & 1 & 2 & 3 \\
\hline 500 & - & - & - & - & - & - & $\cdot$ & - & - \\
\hline 250 & - & - & - & - & - & $\cdot$ & - & - & - \\
\hline 125 & - & - & - & $\cdot$ & - & - & - & $\cdot$ & $\cdot$ \\
\hline 62.5 & - & - & - & - & - & - & - & - & - \\
\hline 31.2 & - & - & - & - & - & $\cdot$ & - & - & - \\
\hline 15.6 & $\cdot$ & - & + & - & - & - & + & - & - \\
\hline 7.8 & + & + & + & - & - & - & + & + & + \\
\hline 3.9 & + & + & + & - & + & - & + & + & + \\
\hline 1.9 & + & + & + & + & + & + & + & + & + \\
\hline 0.9 & + & + & + & + & + & + & + & + & + \\
\hline 0.4 & + & + & + & + & + & + & + & + & + \\
\hline 0.2 & + & $\dot{t}$ & + & + & + & + & + & + & + \\
\hline 0.1 & + & + & + & + & + & + & + & + & + \\
\hline
\end{tabular}

Keterangan (Remarks):

* = diamati berdasarkan kekeruhan media (assessment based on turbidity of the media)

. = bakteri tidak tumbuh (no growth of bacteria)

$+=$ bakteri tumbuh (bacteria growth)

= Konsentrasi Efektif Terendah (Minimuim Effective Concentration) 
Tabel 4. Pengaruh desinfeksi induk terhadap kepadatan Vibrio harveyi (cfu/mL), daya tetas telur (\%) dan daya gerak larva kepiting bakau dengan infeksi $V$. harveyi pada kepadatan $10^{3}$ $\mathrm{cfu} / \mathrm{mL}$

Table 4. Effect of spawner disinfection on density of Vibrio harveyi $(c f u / m L)$, hatching rate (\%), and vitality of mangrove crab larvae with $V$. harveyi infection density of $10^{3} \mathrm{cfu} / \mathrm{mL}$.

\begin{tabular}{|c|c|c|c|}
\hline $\begin{array}{l}\text { Perlakuan antibiotik } \\
\text { Antibiotic treatment }\end{array}$ & $\begin{array}{c}\text { Kepadatan } V \text {. harveyi } \\
\text { Density of } V \text {. harveyi } \\
\text { (cfu/mL) }\end{array}$ & $\begin{array}{c}\text { Daya tetas telur } \\
\text { Hatching rate } \\
(\%)\end{array}$ & $\begin{array}{c}\text { Kinerja larva } \\
\text { Performance of larvae }\end{array}$ \\
\hline OTC (31.2 mg/L) & $3.0 \times 10^{3}$ & $92.33 \pm 2.5166^{b}$ & Baik (Good) \\
\hline Prefuran (7.8 mg/L) & $1.0 \times 10^{3}$ & $95.00 \pm 2.000^{b}$ & Baik (Good) \\
\hline Furazolidone (31.2 mg/L) & $5.0 \times 10^{3}$ & $87.67 \pm 2.5166^{b}$ & Baik (Good) \\
\hline Kontrol (Control) & $1.3 \times 10^{3}$ & $24.00 \pm 7.9373^{a}$ & Lemah (Feeble) \\
\hline
\end{tabular}

pada masa-masa ini telur berada di luar tubuh sehingga peluang untuk terinfeksi patogen lebih besar.

\section{KESIMPULAN}

1. Isolat Vibrio harveyi dari larva kepiting bakau stadia zoea-1. V. harveyi bersifat patogen terhadap larva kepiting bakau.

2. Konsentrasi efektif terendah dari OTC, prefuran dan furazolidon terhadap $V$. harveyi masingmasing adalah $31,2 \mathrm{mg} / \mathrm{L}, 7,8 \mathrm{mg} / \mathrm{L}$ dan 31,2 $\mathrm{mg} / \mathrm{L}$.

3. Desinfeksi induk pada masa pengeraman telur menggunakan ketiga macam antibiotik pada konsentrasi efektif terendahnya ternyata mampu menurunkan kepadatan $V$. harveyi pada larva, serta meningkatkan daya tetas telur dan daya gerak larva.

\section{DAFTAR PUSTAKA}

Aoki, T. 1992. Chemotherapy and drug resistance in fish farms in Japan. In Shariff, M., Subasinghe, R.P. and Arthur, J.R. (Eds.), Diseases in Asian Aquaculture I, Fish Health Section, Asian Fisheries Society, Manila, Philippines. 519-529.

Baticados, M.C.L.and Paclibare, J.D. 1992. The used of chemotherapeutic agents in aquaculture in the Philippines. In Shariff, M., Subasinghe, R.P. and Arthur, J.R. (Eds.), Diseases in Asian Aquaculture I, Fish Health Section, Asian Fisheries Society, Manila, Philippines. 531-546.

Baumann, P., Furnis, A.L. and Lee, J.V. 1984. Facultatively anerobic gram-negative rods. In Krieg, N.R. (Eds.), Bergey's Manual of Systematic
Bacteriology. Vol. 1. Williams \& Wilkins, Baltimore, USA.

Bian, B.Z.. Hatai, K., Lio-Po, G.D. and Egusa, S. 1979. Studies on the fungal diseases in crustaceans I : Lagenidium scyllae sp. nov. isolated from cultivated ova and larvae of the mangrove crab (Scylla serrata). Trans. mycol. Soc. of Japan 20:115-124.

Hatai, K. and Lawhavinit, O. 1988. Lagenidium myophyllum sp. nov. a new parasite on adult northern shrimp, Pandalus borealis Kroyer. Trans. mycol. Soc. Japan 20:115-124.

Holt, J.G., Krieg, N.R., Sneath, P.H.A., Staley, J.T. and Williams, S.T. 1994. Facultatively anaerobic gramnegative rods. In Sneath, P.H.A., Staley, J.T., Brenner, D.J., Holt, J.G., Castenholz, R.W., Schleifer, K., Tully, J.G., Ursing, J., Williams, S.T. (Eds.). Bergeys Manual of Determinative Bacteriology. Ninth Edition. Williams \& Wilkins, Baltimore, Philadelphia, Hong Kong, London, Munich, Sydney, Tokyo: 259-289.

Muroga, K., Suzuki, K., Ishibashi, N. and Nogami, K. 1989. A vibriosis occuring in zoeal larvae of swimming crab, Portunus trituberculatus. Suisanzoshoku, 37:133-141.

Roza, D., Zafran, Parenrengi, A. dan Taufik, A. 1993. Studi pendahuluan penyakit kunang-kunang pada larva kepiting bakau, Scylla serrata. J. Penelitian Budidaya Pantai, 9(3):119-124.

Roza, D. 1996. Pengendalian Vibrio harveyi pada larva udang windu (Penaeus monodon) secara probiotik. Makalah pada Seminar Nasional Mikrobiologi Lingkungan II, Lembaga Ilmu Pengetahuan Indonesia. Bogor, 9-10 Oktober 1996. 10 pp.

Roza, D. 1997. Tingkat keganasan dan penanggulangan bakteri Vibrio bercahaya pada larva kepiting bakau (Scylla serrata). Prosiding II Seminar Nasional 
Biologi XV, Perhimpunan Biologi Indonesia, Bandár Lampung. 501-504

Roza, D., Johnny, F., Zafran, Yunus dan Yuasa, K. 1997. Studi pendahuluan tentang pengaruh $\mathrm{pH}$ terhadap Lagenidium sp. pada larva kepiting bakau (Scylla serrata Forskal). Disajikan pada Simposium Perikanan Indonesia II, Pusat Penelitian dan Pengembangan Perikanan. Ujung Pandang, 3-4 Desember 1997. 11 pp.

Ruangpan, L. and T. Kitao. 1992. Minimal inhibitory concentration of 19 chemotherapeutants against Vibrio bacteria of shrimp, Penaeus monodon. In
Shariff, M. Subasinghe, R.P. and Arthur, J.R (Eds.), Diseuses in Asian Aquaculture I. Fish Health Section, Asian Fisheries Society, Manila, Philippines. 135-142.

Yunus, I. Setyadi, Kasprijo dan Roza, D. 1998. Pengaruh pemberian jenis fitoplankton yang berbeda terhadap sintasan larva kepiting bakau (Scylla serrata). Laporan Penelitian Loka Penelitian Perikanan Pantai Gondol, Bali. 15 pp.

Zafran, Roza, D. dan Parenrengi,A. 1993 Karakterisitik dan penanggulangan jamur Lagenidium sp. pada larva kepiting bakau, Scylla serrata. J. Penel. Budidaya Pantai 9(4):29-39. 